\title{
Developing Farmers and Fisherfolks Entrepreneurial Capacity towards Community Based-Enterprise
}

\author{
Nerisa N. Paladan \\ Agribusiness Department, Partido State University, Philippines
}

\begin{abstract}
The study assessed the level of personal entrepreneurial competencies of farmers and fisherfolks towards communitybased enterprise engagement. Specifically, it determines which competencies they excel in, recognizes the differences of entrepreneurial competency in terms of gender, business experience, and educational attainment and its correlation to age. Furthermore, the framework was developed in implementing community-based enterprises. Descriptive research was adopted; 206 farmers and 100 fisherfolks are the respondents of this study; they were surveyed, and assessed the level of entrepreneurial competencies using the Personal Entrepreneurial Competencies (PEC) Questionnaire with fiftyfive questions through Likert scale. Findings reveal that farmers and fisherfolks have a moderate entrepreneurial competency; both rank first the risk-taking and goal setting as the least. Farmer self-confidence increases as they age while for fisherfolks it declines; male farmers are more persuasive, farmers with business experience have higher competency for opportunityseeking and risk-taking, and farmers' competency differs in terms of their educational attainment. While fisherfolks show no difference in entrepreneurial competency for both men and women, with or without business experience, and only the competency for persistence differ in their educational attainment. Developing a framework for implementing community-based enterprise should focus on intensifying the entrepreneurial competency of farmers and fisherfolks.
\end{abstract}

Keywords: Entrepreneurial competency, farmers, fisherfolks, community-based enterprise

\section{INTRODUCTION}

$\mathrm{U}$ nited Nations recognize the role of local communities and emphasize the relevance of leveraging their potential for achieving the Sustainable Development Goals (SDGs) (e.g., United Nations, 2015; UNDP, 2018; UNDP Environment and Energy Group, 2010). With this it can be noticed the emergence of alternative forms of communitybased organizations that promote sustainable and resilient local economies (Daskalaki et al., 2015; Dubb, 2016). Community-based enterprise is one of the forms of organization that has gained prevalence, an enterprise that are conventional, owned and controlled by the members of a local community, they are recognized and its purpose is to generate economic, social and/or ecological benefits (Hertel \& Belz, 2017). Through joining forces, local communities have the capacity to create enterprises that tackle local problems and generate multiple benefits unattainable to individual entrepreneurs (Peredo \& Chrisman, 2006) and farmers and fisherfolks can capitalize in engaging into community-based enterprise.
Since agriculture encompasses an enormous role in ensuring a sustainable development (Asence, 2016) and it accounted for $32 \%$ of the full global employment (ILO, 2014). Moreover, agriculture is the main occupational sector within the developing countries, and with the poorest countries being those with mostly agricultural economies and societies (FAO). Agriculture had been the backbone of manypeopleliving in countryside areas worldwide and investment within the agricultural sector has been revealed to be effective means to spice up groups out of poverty (Bennell, 2010; Diao \& Hazel, \& Thurlow, 2010). Hence, the challenge for farmers and fisherfolks is to level-up farming to agribusiness, upgrade into modern farming and join force to develop their community-based enterprise.

Entrepreneurial competency is needed when farmers and fisherfolks will take advantage of the opportunities of agribusiness, upgrade into modern farming and develop their community-based enterprise and it incorporates a significant part in considering such practical approaches with the environment. Thus, the role of an entrepreneur's competency is a vital factor in attaining quality in performance to ensure sustainable growth and success of a venture amidst a competitive business environment. The worth of entrepreneurial competency has amplified during the previous decades due to the deliberate role played by the human factor, mostly the entrepreneur of a business enterprise (Kochadai, 2011) and therefore the characteristics of entrepreneurship and entrepreneurial competence become an inseparable unity to enhance the performance of the breeder's business (Mubarak, et.al, 2019). On the contrary, entrepreneurship could be a new situation for several farmers (Bergevoet et al. 2005 in Arellano \& Delos Reyes, 2019). Boosting entrepreneurial qualities and competencies is a vital skill in shaping farmer's entrepreneurial intentions (Mubarak, et.al, 2019).

Entrepreneurship is defined as "the usage of reserved inventiveness to convert a simple farming concept into a practical new farming enterprise. It could also involve diversifying an existing farming enterprise and inspiring it to grow "' (Kahan, 2013, Arellano \& Delos Reyes, 2019) through promoting community-based enterprise that offers a hopeful method towards poverty reduction in underprivileged communities to the limited extent (Parwez, 2017) just like the Philippines where poverty is still a major concern particularly in the agricultural sector.

In a global perspective, the Philippine with its rich natural agricultural resources have a large potential to contribute to 
the global food security and tourism industry through promoting entrepreneurship and community-based enterprise development for farmers and fisherfolks. In support to promote entrepreneurship to farming, the Philippines government crafted RA 11321 or the "Sagip Saka Act" instituting the farmers and fisher folk enterprise program of the department of agriculture which aims to ensure sustainability of agriculture and fishing enterprise.The Philippine agriculture will continue to progress as it understands that an entrepreneurial and innovative environment begins with the people who work in the farm.

Farming and fishing are among the highest contributing sectors within the Philippine economy and society. In a recent study of Baticados (2018), different entrepreneurial activities associated with agricultural-related trade and lower-end services in rural areas and the urban poor as well as the businesses of the non-poor contributed to the $15 \%$ drop in poverty in the country. Forming farmers and fisherfolks into a ccommunity-based enterprise offers a capable approach towards poverty reduction (Parwez, 2017). As Filipino farmers and fisherfolks continue to shift to a market-centered orientation from its traditional production orientation, it can expect a robust increase in our economic sector by at least 38 to $40 \%$ compared to a 9 to $11 \%$ GDP if the focus is on agricultural production alone.

However, entrepreneurship and community-based enterprise is not generally practiced or even stimulated in countryside or rural areas and has remained relatively little emphasis in either agricultural or business literature. Experimental research on rural/countryside entrepreneurship is moderately rare and this model remains basically unfamiliar, and even unusual are the ones involving it to technical efficiency (Arellano \&Delos Reyes, 2019). A study, therefore, on the entrepreneurial competencies of farmers and fisherfolks towards development of community-based enterprise is vital. Aside from entrepreneurial competency, leadership is the utmost critical element for the achievement of community-based enterprises (Anderson et al. 2006). To achieve business success in establishing community-based enterprise, a farmer and fisherfolks needs to make strategic, as well as innovative, decisions concerning all levels of the business and improving competencies can be a way to improve entrepreneurial success (Bergevoet. et al. 2005). Therefore, farmers and fisherfolks rely on entrepreneurial competencies and characteristics to enable them to become more successful in their communitybased enterprise.

\section{LITERATURE REVIEW}

\subsection{Entrepreneurial Competency}

Man, Lau, and Chan (2002); Phelan (2014) stated that entrepreneurial competencies can be referred to as actions like assessing information, recognizing customer needs, scanning the environment, articulating strategies, carrying networks together, enchanting initiative, presenting diversity, and collaboration. Likewise, entrepreneurial competency has a critical role in taking such proactive approaches with the environment. Thus, the role of an entrepreneur's competency is vastly critical aspect in realizing excellence in performance to guarantee sustainable development and success of an enterprise amidst a viable business environment (Kochadai 2011).

Successful entrepreneurs are recognized to have firm entrepreneurial skills that embraces the skill to solve business problems and to familiarize to the changing environment (Nieman et al, 2004). Entrepreneurial competence can be referred to a kind of human investment that encompassed skills that are vital for the awareness of their capacities (Mujuru, 2014). Also, Zapata and Bruto (2017) stated that competencies are needed to build and improve the company's performance in the future or as a foundation for the company's competitiveness in the long term similar to farmers and fisherfolks community-based enterprise.

According to Herliana, et.al, (2019) the growth of entrepreneurial skills is desired for farmers to advance their business to flourish just like the agribusiness situation. To realize business success, a farmer requires to develop a planned, be innovative, makes decision related to all stages of the business. Hence, farmers depend on entrepreneurial competencies and characteristics to empower them to become more successful. The topic of entrepreneurial competencies has increased in popularity as a way for determining entrepreneurial behavior among individuals. According to Nieuwoudt et.al, (2017) the entrepreneurial competencies, connected with behavior and decision-making skills, have been confirmed to have an encouraging influence to the financial performance of a business. Previous research has showed that there is a positive influence between entrepreneurship competencies and business performance, which means that the higher the entrepreneurship competencies will have a positive effect on business performance (Mubarak, et.al, 2019).

There are 10 entrepreneurial competencies identified by Man (2001) stated by (Nieuwoudt, 2016). These competencies are: opportunity competencies, relationship competencies, conceptual competencies (analytical competencies and innovative competencies), organizing competencies (operational competencies and human competencies), strategic competencies, commitment competencies, learning competencies and personal strength competencies. According to Nieuwoudt et.al, (2017) entrepreneurial competencies, as a whole, indicate that a farmer needs to focus on several competencies at the same time, in consequence of which certain competencies will be neglected. For instance, McElwee (2008) recommends that networking, innovation, risk taking, team working, reflection, leadership and business monitoring are essential to emerging and cultivating the farm business. Within the business, farmers need to be owners, at the same time managers and a worker, which generates an increased mandate on the farmer to execute well on numerous levels. Though, if farmers focus on individual competencies, they will be able to recognize where they are missing and make use of essential measures to counter this. Thus, the 
management of a farm means that a farmer desires to be competent in all of the competencies.

Thus, what farmers need right now is to develop new skills and competencies to remain competitive. As Lans, et al. (2008) have emphasized, the factual potential of concentrating on entrepreneurial competence lies in (1) making the smallbusiness owner aware of his / her own competence level, (2) recognizing the importance of detailed competencies to business success, and (3) providing succeeding direction and guidance in competence and skill expansion. Entrepreneurial intentions of farmers are affected by establishing entrepreneurial characteristics and competencies (Mubarak, et.al, 2019).

\subsection{Community Based Enterprise}

Community-based enterprises emerge in both developing and the developed worlds in its different locales, including villages, regions or suburbs. To promote entrepreneurship to the farmers and fisherfolks and in the rural areas, communitybased enterprise was introduced to them. According to Peredo \& Chrisman (2006), community-based enterprise can be an effective means to eradicate poverty, empower local farmers (Handy et al., 2011) and women (Torri \& Martinez, 2011), offer sustainable, local energy systems (Cieslik, 2016), complement indigenous communities' culture and needs with market requirements (Giovannini, 2014), line up sustainable resource management and the commercial usage of biodiversity (Garcia-Lopez, 2013), revitalize deprived regions after socioeconomic crises (Johnstone \&Lionais, 2004), and recompense for the loss of local community assets instigated by socio-demographic variations and cuts in governmental expenditures (Haugh, 2007).

According to Lawson, and Kearns, (2010) critical analysis advocates that community engagement generates a sense of responsibilities for communities in terms of taking care of their surroundings. Likewise, the benefits of community participation in a society are very extensive; some would say it is very comprehensive. Succeeding decades of specialized or state-led interventions, have seen, that community has been a significant knowledge resource, if seized, will lead to improved and accountable services. Several studies (Rydin, and Pennington 2000; Maguire, and Truscott 2006) states that community engagement aspect is based upon the modest principle that the community knows best about their own problems, thus permitting policy makers to act accordingly. Acharya, K \& Acharya S, (2007) state that the accessibility of local market, skills and local raw materials joint with a strong institutional support are keys for the successful communitybased enterprises.

Peredo and Chrisman (2006) theoretically derive four factors that trigger the emergence of collective entrepreneurial action, namely: the presence of multi-faceted social, cultural, ecological, political and economic problems; a tradition of collective action; a deposit of social capital and social networks; and a medium community size that ensures a resource base of a certain size while, at the same time, securing the strength of the social bonds and networks between the local inhabitants. There are six-stages in the process of community-based enterprise creation including opportunity identification; idea articulation; idea ownership; stakeholder mobilization; opportunity exploitation; and stakeholder reflection (Haugh, 2007). According to the stages, the enterprise creation process begins with the acknowledgment of an unfulfilled need within a local community. Next, the idea givers share their thoughts, develop an initial business idea, create a formal team, and assemble the required resources. Following this, with the support of the local community, they develop, evaluate and implement a business plan, form a legal business, and, finally, enter the market. Though the six-stages serves as a clear starting point through providing an objective that describe how the enterprise creation process unfold over time, however it still needs an understanding of the dynamics that trigger and fuel this process (Hertel \& Belz, 2017).

There is need to improve the entrepreneurial competency of farmers and fisherfolks having presented the significant of entrepreneurial competency for the success and sustainability of the community-based enterprise. However, Lumpkin et al., (2018) state that researchers and practitioners approve on the available potential of community-based enterprises and study on this phenomenon is still in its infancy. Thus far, most of the research has remained descriptive (Hertel \& Belz, 2017) and still little about how these enterprises emerge (Daskalaki et al., 2015) or why some communities are more amenable to community-based entrepreneurship (Peredo \& Chrisman, 2006). Nevertheless, to leverage onthe transformative capacity of rural communities, which is crucial for the achievement of the SDGs, it must gain a more nuanced understanding of the underlying instruments and dynamics of effective communitybased enterprise formation. Lastly, Anderson et al. (2006) state that for a community-based enterprise to be successful leadership is the most critical element that need to take into account.

\section{METHODOLOGY}

The study utilized a descriptive quantitative research design to determine the level of personal entrepreneurial competencies of the farmers and fisherfolks. A descriptive study is more structured and exploratory thus providing an accurate and valid representation of people, situations or events and information on the current state of a phenomenon (Rahi, 2017) which is appropriate to this study. It will assess the personal entrepreneurial competencies using Personal Entrepreneurial Competencies (PEC) Questionnaire with fiftyfive (55) questions through Likert scale. Moreover, this will also use qualitative research design through an unstructured interview with the participants.

This study was conducted in the town of San Jose and Sagnay, Camarines Sur. The populations of the study are the farmers and fisherfolks in selected areas in San Jose and Sagnay, Camarines Sur. Using sloven formula a sample of two hundred six (206) farmers and one hundred (100) fisherfolks 
was identified as respondent of this study.One of the criteria in choosing the respondents of the study was the farmers and fisherfolks should have interest in engaging in enterprise development.

Data were collected through a survey with a structured questionnaire, interview, and observation. It uses a five Likert-type test based on scale from "always to never" to measure the level of personal entrepreneurial competencies using Personal Entrepreneurial Competencies (PEC) questionnaire of farmers and fisherfolks respondent.

Oral consent was provided by the farmers and fisherfolks respondent to participate in this study after a short orientation of the research objectives. Confidentiality was assured on their responses and the voluntary nature of the interviews.

The research questionnaire used in this study was developed based on published literatures on entrepreneurial competency. The first part of the questionnaire was the demographic profile of the respondent that includes sex, age, education attainment and business experience. Followed by the personal entrepreneurial competency questionnaire (PEC) with 55 items to measure 10 PECs with different indicator questions. These PECs include opportunity seeking, persistence, committed to work contract, demand for quality/efficiency, risk-taking, goal- setting, information seeking, systematic planning and monitoring, persuasion and networking, and self- confidence (Diaz et al. 1997 cited by Depositario, et al. 2011). PEC scores were interpreted using the following: 20 25 Very Strong; 15-19 Strong; 10-14 Moderate; 5-9 Fair; 0-4 Weak.

A descriptive of the frequency and percentage for the demographic, weighted mean for the level of personal entrepreneurial competency, Pearson Correlation for the significant relation, T-test Independent and One-Factor ANOVA one way for the differentiation was provided. Descriptive statistics helped to describe the personal entrepreneurial competency of farmers and fisherfolks. The descriptive statistics were initially obtained and analyzed to understand relationship, significance, and differentiation. According to Al and Bhaskar (2016), descriptive statistics provide a summary of the data and "try to describe the relationship between variables in a sample or population" (p.55). A Pearson's correlation analysis was also conducted. With the Pearson's correlation analysis, it determined whether there was a significant positive or negative correlation between the age and the personal entrepreneurial competency being studied. By using the Pearson's correlation coefficients, it determined whether an increase in age results in an increase, decrease, or no change in the level of personal entrepreneurial competency. The significance of the relationship was based on a 0.05 level of significance.

\section{RESULT and DISCUSSION}

\subsection{Demographic Profile of Respondent}

The profile of the respondents of this study is reflected in table 1. The farmers and fisherfolks are the two groups' respondents of this study. For the farmers respondent there were $70 \%$ women and 30\% men while for fisherfolks respondent $68 \%$ men and $32 \%$ women. It was observed that in farming women are now participating while in fishing this is still dominated by men. However, women should be part of the decision making in farming and fishing as they are more marginalized due to tradition/ culture. In terms of age, both farmers and fisherfolks respondent majority are from age 41 and above. This indicate that farmers and fisherfolks are getting aged and few of the young generation are interested in farming and fishing. In general, youths aren't that interested in agriculture. Most have preconception that agriculture is always equated to farming. Several studies stated that youths' first impression about a career is important. Thus, entrepreneurship should leave a positive impression on them. (Heinart\& Roberts,2016).

In terms of educational attainment, majority of farmers have reached college level to graduate while the majority of the fisherfolks have reached high school level to high school graduate. With regards to business experience both farmers and fisherfolks majority has business experience.

Table 1 - Profile of the Respondent

\begin{tabular}{|c|c|c|c|c|}
\hline \multirow[b]{2}{*}{$\begin{array}{l}\text { Demographic } \\
\text { Characteristic }\end{array}$} & \multicolumn{2}{|c|}{ Farmers } & \multicolumn{2}{|c|}{ Fisherfolks } \\
\hline & $\begin{array}{c}\mathrm{n}= \\
(206)\end{array}$ & $\%$ & $\begin{array}{c}\mathrm{n}= \\
(100)\end{array}$ & $\%$ \\
\hline \multicolumn{5}{|c|}{ Gender } \\
\hline Male & 62 & $30 \%$ & 68 & $68 \%$ \\
\hline Female & 144 & $70 \%$ & 32 & $32 \%$ \\
\hline \multicolumn{5}{|c|}{ Age } \\
\hline $18-30$ & 24 & $12 \%$ & 14 & $14 \%$ \\
\hline $31-40$ & 34 & $16 \%$ & 19 & $19 \%$ \\
\hline $41-50$ & 52 & $25 \%$ & 26 & $26 \%$ \\
\hline $51-60$ & 45 & $22 \%$ & 20 & $20 \%$ \\
\hline $61 \&$ above & 51 & $25 \%$ & 21 & $21 \%$ \\
\hline \multicolumn{5}{|c|}{ Educational Attainment } \\
\hline College Graduate & 33 & $16 \%$ & 3 & $3 \%$ \\
\hline College level & 39 & $20 \%$ & 10 & $10 \%$ \\
\hline High School Graduate & 34 & $17 \%$ & 19 & $19 \%$ \\
\hline High School Level & 37 & $18 \%$ & 26 & $26 \%$ \\
\hline Elementary Graduate & 23 & $11 \%$ & 24 & $24 \%$ \\
\hline Elementary Level & 40 & $19 \%$ & 18 & $18 \%$ \\
\hline \multicolumn{5}{|c|}{ Business Experience } \\
\hline $\begin{array}{l}\text { With Business } \\
\text { Experience }\end{array}$ & 144 & $70 \%$ & 94 & $94 \%$ \\
\hline $\begin{array}{l}\text { Without Business } \\
\text { Experience }\end{array}$ & 62 & $30 \%$ & 6 & $6 \%$ \\
\hline
\end{tabular}

\section{B. Entrepreneurial Competency of Farmers and Fisher}

folks

Table 2 indicates the farmer's and fisherfolks personal 
entrepreneurial competency using weighted mean. That nine (9) out of 10 indicators of the personal entrepreneurial competency the farmers have moderate competency and one (1) fair competency. While fisherfolks reflects eight (8) out ten (10) indicators of the personal entrepreneurial competency they have moderate competency and two (2) fair competencies.

Farmers has moderate competency for opportunity seeking, persistence, commitment to work, demand for quality, risk taking, information seeking, systematic planning, persuasion and networking and self-confidence. They have fair competency in terms goal setting.

While fisherfolks has moderate competency for opportunity seeking, commitment to work, demand for quality, risk taking, information seeking, systematic planning, persuasion and networking and self-confidence. And they have fair competency in terms of persistence and goal setting.

Overall, it was observed that both farmers and fisherfolks have moderate competency to most of the indicators of personal entrepreneurial competency. This is reason why there is a need for trainings to improve their personal entrepreneurial competency from moderate to very strong to help them become more entrepreneurial and improve their livelihood. Likewise, improving the entrepreneurial competency of farmers and fisherfolks would be beneficial in the implementation of R.A. no.11321 "an act instituting the farmers and fisherfolk enterprise development program of the department of agriculture" otherwise known as "The Sagip SAKA Act".

Furthermore, it was noted that both farmers and fisherfolks rank $1^{\text {st }}$ risk taking in their personal entrepreneurial competency and goal setting as the least. This indicate that farmers and fisherfolks take risk without setting goal on what they want to accomplish. On the contrary, risk seeking is rarely the case among farmers (Quilloy 2015) and "traditional farmers are rational but risk-averse (reluctant to take risks) (Norton, et al. 2014 in Arellano \& Delos Reyes, 2019)." This also explain why farmers has least personal entrepreneurial competency for goal setting. Since risk averse pertains to someone who does not like the possibility for an undesirable event to occur. They are also, generally $(40 \%)$ weak goalsetters. This might have been their response to the climatic conditions in the area which bring flooding, intense rain, or drought resulting to significant production losses (Arellano \& Delos Reyes, 2019).

Table 2 - Entrepreneurial Competency of Farmers and Fisherfolks

\begin{tabular}{|c|c|c|c|c|c|c|}
\hline $\begin{array}{c}\text { Personal } \\
\text { Entrepreneuria } \\
\text { 1 Competency }\end{array}$ & $\begin{array}{c}\text { Farmer } \\
\mathrm{s}\end{array}$ & $\begin{array}{c}\text { Interpreta } \\
\text { tion }\end{array}$ & $\begin{array}{c}\text { Ra } \\
\text { nk }\end{array}$ & $\begin{array}{c}\text { Fisher } \\
\text { folks }\end{array}$ & $\begin{array}{c}\text { Interpreta } \\
\text { tion }\end{array}$ & Rank \\
\hline $\begin{array}{c}\text { Opportunity } \\
\text { Seeking }\end{array}$ & 10.7 & Moderate & 3 & 10.09 & Moderate & 4 \\
\hline
\end{tabular}

\begin{tabular}{|c|c|c|c|c|c|c|}
\hline Persistence & 9.8 & Moderate & 9 & 9.37 & Fair & 9 \\
\hline $\begin{array}{c}\text { Commitment } \\
\text { to Work }\end{array}$ & 10.56 & Moderate & 4 & 10.57 & Moderate & 2 \\
\hline $\begin{array}{c}\text { Demand for } \\
\text { Quality }\end{array}$ & 10.03 & Moderate & 8 & 9.77 & Moderate & 7 \\
\hline Risk taking & 13.68 & Moderate & 1 & 13.14 & Moderate & 1 \\
\hline Goal Setting & 9.21 & Fair & 10 & 9.18 & Fair & 10 \\
\hline $\begin{array}{c}\text { Information } \\
\text { Seeking }\end{array}$ & 10.28 & Moderate & 7 & 10.15 & Moderate & 3 \\
\hline $\begin{array}{c}\text { Systematic } \\
\text { planning }\end{array}$ & 10.35 & Moderate & 6 & 10.07 & Moderate & 5 \\
\hline $\begin{array}{c}\text { Persuasion } \\
\text { and } \\
\text { Networking }\end{array}$ & 10.51 & Moderate & 5 & 9.83 & Moderate & 8 \\
\hline $\begin{array}{c}\text { Self- } \\
\text { confidence }\end{array}$ & 10.88 & Moderate & 2 & 10.00 & Moderate & 6 \\
\hline
\end{tabular}

C. Correlation of Age of Farmers and Fisher folks to

Entrepreneurial Competency

\section{C.1. Relationship of Age with Entrepreneurial Competencies of Farmers}

Results of Pearson correlation reflected in table 3.1 revealed very weak significant relationship between age with information seeking $(r=0.179, p=0.010)$; systematic planning $(r=0.139, p=0.046)$ and persuasion \& networking $(r=-0.198$, $p=0.004$ ). Also, a weak significant relationship exists between age with risk taking $(r=0.285, p=0.000)$ and self-confidence $(r=0.296, p=0.000)$. It was noted that the positive relationship obtained implies that as farmers aged their competency in risk taking, self-confidence, information seeking, systematic planning, and persuasion \& networking increases.

It was observed that as farmers aged, they are more risk taking and advance their self-confidence since they already gain more experience in farming and consider it as a business and explore new ways and technology on how they can improve their farming, it was noted that this contributes to their entrepreneurial competency. Likewise, it was observed as farmers aged their network or linkages in the private sector and government office align with farming increases where they can access more information that can help them in their farming, so they become more information seeking and persuasive. Also, it was noticed that they are systematic in planning when engaging to their farming activities they learned it through several years in farming. This is like the findings that entrepreneurial competencies are directly correlated to technical efficiency (Kahan, D. 2013) and "entrepreneurship characteristics significantly and positively influence business performance when linked together with entrepreneurial competencies as a whole." (Mubarak, et.al, 2019)

\section{C.2 Relationship of Age with Entrepreneurial}

\section{Competencies of Fisherfolks}

Results of Pearson correlation shows in table 3.2 revealed significant weak relationship between age and selfconfidence $(r=-0.242, p=0.015)$. It was noted that a negative 
weak relationship exists which implies that as the fisherfolk aged, their competency in self-confidence decreases. There is no significant relationship between age and the rest of the indicators of personal entrepreneurial competencies.

It was observed that as fisherfolks aged their self-confidence decreases since their physical strength in fishing is deteriorating and they are worried for their livelihood once they could not do anymore fishing and since this is the only livelihood that they know. And it was noted that as fisherfolks aged their entrepreneurial competency did not change or improve since fisherfolks only focus on fishing or if they are selling, they just sell without adding value to the fish that they caught and sell. Therefore, it needs to improve the personal entrepreneurial competency of fisherfolks across ages.

Table 3.1 Correlation between Age and Entrepreneurship Competencies of Farmers

\begin{tabular}{|c|c|c|}
\hline Relationship of Age with & $\begin{array}{c}\text { Correlation } \\
\text { Coefficient }\end{array}$ & $\begin{array}{c}\text { P- } \\
\text { value }\end{array}$ \\
\hline Opportunity Seeking & 0.086 & 0.219 \\
\hline Persistence & 0.112 & 0.108 \\
\hline Commitmentto Work & 0.015 & 0.829 \\
\hline Demand for Quality & 0.106 & 0.130 \\
\hline Risk taking & 0.285 & 0.000 \\
\hline Goal Setting & -0.003 & 0.969 \\
\hline Information Seeking & 0.179 & 0.010 \\
\hline Systematic planning & 0.139 & 0.046 \\
\hline Persuasion and Networking & 0.198 & 0.004 \\
\hline Self-confidence & 0.296 & 0.000 \\
\hline
\end{tabular}

Table 3.2 Correlation between Age and Entrepreneurship Competencies of Fisherfolks

\begin{tabular}{|c|c|c|}
\hline Relationshipof Age with & $\begin{array}{c}\text { Correlation } \\
\text { Coefficient }\end{array}$ & P-value \\
\hline Opportunity Seeking & -0.130 & 0.196 \\
\hline Persistence & 0.009 & 0.930 \\
\hline Commitmentto Work & -0.167 & 0.096 \\
\hline Demand for Quality & -0.070 & 0.488 \\
\hline Risk taking & -0.058 & 0.565 \\
\hline Goal Setting & 0.003 & 0.975 \\
\hline Information Seeking & -0.053 & 0.599 \\
\hline Systematic planning & -0.184 & 0.067 \\
\hline Persuasion and & 0.141 & 0.161 \\
\hline Networking & -0.242 & 0.015 \\
\hline
\end{tabular}

\section{Differences of Entrepreneurial Competency of Farmers}

and Fisher folks in terms of Gender, Business

Experience and Educational Attainment.

D.1.1 Differences on Entrepreneurship Competencies of

\section{Farmers According to Gender}

Table 4.1 reflects the results of T-test independent show that among the 10 indicators of entrepreneurship competency only Persuasion \& Networking (mean female $=10.25$, mean male $=10.98, \mathrm{p}=0.046)$ revealed significant difference between female and male respectively. It was noted that male has higher competency thanfemale in terms of Persuasion \& Networking. The rest of the indicators show no significant differences under gender.

It was observed that male farmers are more persuasive than their female counterpart. It was noted that male farmers are the one who look for networks and linkages on how they can improve their farming activities and they are also the one who join different organization. And that is the reason why male farmers are more persuasive that women farmers. Moreover, most of the women farmer are also doing household chores and they have limited time to associate or join an organization/association and lobby to different stakeholders that can help them in farming and their livelihood.

Table 4.1 Entrepreneurial Competencies of Farmers according to Gender

\begin{tabular}{|c|c|c|c|}
\hline \multirow{2}{*}{ Indicators } & \multicolumn{2}{|c|}{ Mean Score } & \multirow{2}{*}{$\begin{array}{c}\text { P- } \\
\text { value }\end{array}$} \\
\cline { 2 - 3 } & Female & Male & 0.454 \\
\hline Opportunity Seeking & 10.63 & 10.78 & 0.835 \\
\hline Persistence & 9.83 & 9.78 & 0.519 \\
\hline Commitment to Work & 10.63 & 10.49 & 0.519 \\
\hline Demand for Quality & 9.85 & 10.20 & 0.142 \\
\hline Risk taking & 13.42 & 13.94 & 0.222 \\
\hline Goal Setting & 9.15 & 9.27 & 0.616 \\
\hline Information Seeking & 10.19 & 10.37 & 0.349 \\
\hline Systematic planning & 10.31 & 10.39 & 0.733 \\
\hline $\begin{array}{c}\text { Persuasion and } \\
\text { Networking }\end{array}$ & 10.25 & 10.98 & 0.046 \\
\hline Self-confidence & 10.56 & 11.19 & 0.060 \\
\hline
\end{tabular}

\section{D.1.2 Differences on Entrepreneurship Competencies of}

\section{Fisherfolks According to Gender}

Table 4.2 reflects the results of T-test independent that show no significant differences on personal entrepreneurship competency between male and female fisherfolks along the 10 indicators. It was noticed that personal entrepreneurial competency of both male and female fisherfolks is not affected by their gender. That regardless of the gender of fisherfolks their personal entrepreneurial competencies have no difference. It was noticed that both male and female fisherfolks have the same style of doing their fishing or selling fish activities. Like if they are selling fish, both just sell the fish without adding value. It was further noticed that when there is greatcatch fish, they just sell it without considering the supply and demand theory, adding value or applying strategy where they can minimize the lowering of price due to the increase of supply. Given this observation, fisherfolks need to improve their personal entrepreneurial competency to level-up 
or upgrade their strategy in their fishing activities.

Table 4.2 Entrepreneurial Competencies of Fisherfolks according to Gender

\begin{tabular}{|c|c|c|c|}
\hline \multirow[b]{2}{*}{ Indicators } & \multicolumn{2}{|c|}{ Mean Score } & \multirow{2}{*}{$\begin{array}{c}P \text { - } \\
\text { value }\end{array}$} \\
\hline & Female & Male & \\
\hline Opportunity Seeking & 10.44 & 9.93 & 0.275 \\
\hline Persistence & 9.44 & 9.34 & 0.759 \\
\hline $\begin{array}{l}\text { Commitment } \\
\text { to Work }\end{array}$ & 10.78 & 10.47 & 0.324 \\
\hline Demand for Quality & 9.91 & 9.71 & 0.623 \\
\hline Risk taking & 13.34 & 13.04 & 0.613 \\
\hline Goal Setting & 8.81 & 9.35 & 0.173 \\
\hline Information Seeking & 10.09 & 10.18 & 0.837 \\
\hline Systematic planning & 10.28 & 9.97 & 0.421 \\
\hline $\begin{array}{l}\text { Persuasion and } \\
\text { Networking }\end{array}$ & 9.53 & 9.97 & 0.272 \\
\hline Self-confidence & 10.06 & 9.97 & 0.806 \\
\hline
\end{tabular}

\section{D.2.1 Differences on Entrepreneurship Competencies of}

\section{Farmers According to Business Experience}

Table 5.1 shows the results of T-test independent that among the 10 indicators of personal entrepreneurial competency only Risk Taking (mean no $=12.44$, mean yes $=14.22, \mathrm{p}=0.000$ ) revealed significant difference between with farmers with business experience and with no business experience. It was noted that farmers with business experience have higher competency with farmers without business experience in terms of risk taking. The rest of the indicators show no significant differences under business experience.

It was noticed that farmers with business experience are more risk taker as compared to those farmers without business experience. It was observed that farmers with business experience would usually invest, adopt \& used the technology upgrading their farming business since they are aware that they need to take risk and embrace innovation. It was noted that farmers without business experience are hesitance in taking risk to improve their farming engagement since their experience is limited only to farming and have not yet shift, their mindset into farming business.

Table 5.1 Entrepreneurial Competencies of Farmers according to Business Experience

\begin{tabular}{|c|c|c|c|}
\hline \multirow{2}{*}{ Indicators } & \multicolumn{2}{|c|}{ Mean Score } & \multirow{2}{*}{} \\
\cline { 2 - 3 } & No & Yes & $\begin{array}{c}\text { P- } \\
\text { value }\end{array}$ \\
\hline Opportunity Seeking & 10.17 & 10.09 & 0.903 \\
\hline Persistence & 9.17 & 9.38 & 0.560 \\
\hline Commitment to Work & 10.83 & 10.55 & 0.695 \\
\hline Demand for Quality & 10.00 & 9.76 & 0.700 \\
\hline Risk taking & 12.50 & 13.18 & 0.474 \\
\hline Goal Setting & 8.83 & 9.20 & 0.736 \\
\hline
\end{tabular}

\begin{tabular}{|c|c|c|c|}
\hline Information Seeking & 9.83 & 10.17 & 0.614 \\
\hline Systematic planning & 10.00 & 10.07 & 0.921 \\
\hline Persuasion and Networking & 9.67 & 9.84 & 0.724 \\
\hline Self-confidence & 9.83 & 10.01 & 0.836 \\
\hline
\end{tabular}

\section{D.2.2 Differences on Entrepreneurship}

\section{Competencies of Fisherfolks According to}

\section{Business Experience}

Table 5.2 indicates the results of T-test independent which shows that there is no significant differences on personal entrepreneurial competency between those fisherfolks with and without business experience along the 10 indicators. It was observed that the entrepreneurial competency of fisherfolks with business experience and without business experience are just the same.

Since those fisherfolks with business experience focuses only on selling without adding value to the fish that they are selling. Their business experience is limited to trading of fish, and it was observed that fisherfolks goal is also limited to selling the fish that they have within the day and augment to their daily needs. This could be the reason why the personal entrepreneurial competency of fisherfolks with business experience is just the same with those without business experience since there is no innovation on how the fisherfolks trade.

Table 5.2 Entrepreneurial Competencies of Fisherfolks according to Business Experience

\begin{tabular}{|c|c|c|c|}
\hline \multirow{2}{*}{ Indicators } & \multicolumn{2}{|c|}{ Mean Score } & \multirow{2}{*}{} \\
\cline { 2 - 3 } & No & Yes & $\begin{array}{c}\text { P- } \\
\text { value }\end{array}$ \\
\hline Opportunity Seeking & 10.26 & 11.90 & 0.003 \\
\hline Persistence & 9.48 & 9.94 & 0.080 \\
\hline Commitment to Work & 10.60 & 10.64 & 0.807 \\
\hline Demand for Quality & 9.95 & 10.06 & 0.683 \\
\hline Risk taking & 12.44 & 14.22 & 0.000 \\
\hline Goal Setting & 9.13 & 9.24 & 0.616 \\
\hline Information Seeking & 10.23 & 10.31 & 0.684 \\
\hline Systematic planning & 10.26 & 10.39 & 0.614 \\
\hline $\begin{array}{c}\text { Persuasion and } \\
\text { Networking }\end{array}$ & 10.63 & 10.47 & 0.576 \\
\hline Self-confidence & 10.55 & 11.02 & 0.158 \\
\hline
\end{tabular}

\section{D.3.1 Differences on Entrepreneurship Competencies of}

\section{Farmers According to Educational Attainment}

Results of One-factor ANOVA one-way is reflected in table 6.1 which shows significant differences on personal entrepreneurial competencies along educational attainment under risk taking $(\mathrm{p}=0.012)$, information seeking $(\mathrm{p}=0.032)$, persuasion $\&$ networking $(\mathrm{p}=0.014)$ and self-confidence 
$(\mathrm{p}=0.013)$.

Under risk taking, Post Hoc analysis shows elementary graduate has the highest competency (14.68). There are no significant differences among elementary level (14.63), high school graduates (12.94), and college graduate (12.94). However, there is a significant difference among high school level (14.19) and college level which is also the lowest competency (12.82). It was noticed that farmers who are elementary graduate are risk taker since they consider limited factors unlike the college level, they are least risk taker because they look into several factors before deciding to take a risk and consider how they will minimize the risk of uncertainty.

Under information seeking, Post Hoc analysis shows college level has the highest competency (10.67). There are no significant differences among elementary level (10.48), elementary graduate (10.32), college graduate (10.27), and high school level (10.19). High school graduates have the lowest competency (9.65). It was observed that farmers who reach college level are keen seeking more information on how they can improve and upgrade their farming activities while farmers who are high school graduates have the tendency to be complacent and contented on what they already know and for them that is already enough since they can survive.

Under persuasion \& networking, Post Hoc analysis shows college graduates has the highest competency (10.94). There are no significant differences among elementary level (10.83), elementary graduate (10.59), college level (10.59), and high school level (10.49). High school graduates have the lowest competency (9.53). It was noted that farmers who are college graduate are persuasive and have created several networks that can help them in their farming activities.

Under self-confidence, Post Hoc analysis shows high school level has the highest competency (11.87). There are no significant differences among elementary level (10.45) and college graduate (10.03). However, there are significant differences among elementary graduates (11.64), college level (10.95) and high school graduate (10.50).

Table 6.1 Entrepreneurial Competencies of Farmers according to Educational Attainment

\begin{tabular}{|c|c|c|c|c|c|c|c|}
\hline \multirow{2}{*}{$\begin{array}{l}\text { Entrepreneurial } \\
\text { Competency } \\
\text { (Indicator) }\end{array}$} & \multicolumn{6}{|c|}{ Educational Attainment } & \multirow[t]{2}{*}{ P-value } \\
\hline & $\begin{array}{c}\text { College } \\
\text { Graduate }\end{array}$ & College level & $\begin{array}{c}\text { Elementary } \\
\text { Graduate }\end{array}$ & $\begin{array}{c}\text { Elementary } \\
\text { Level }\end{array}$ & $\begin{array}{c}\text { High School } \\
\text { Graduate }\end{array}$ & $\begin{array}{c}\text { High School } \\
\text { Level }\end{array}$ & \\
\hline Opportunity Seeking & 10.33 & 10.64 & 10.59 & 11.03 & 10.62 & 10.95 & 0.283 \\
\hline Persistence & 9.58 & 10.21 & 10.09 & 9.73 & 9.74 & 9.60 & 0.495 \\
\hline Commitment to work & 11.03 & 10.46 & 9.77 & 10.55 & 10.77 & 10.57 & 0.138 \\
\hline Demand for Quality & 10.12 & 9.59 & 9.86 & 10.58 & 10.06 & 9.89 & 0.300 \\
\hline Risk Taking & 12.94 & 12.82 & 14.68 & 14.63 & 12.94 & 14.19 & 0.012 \\
\hline Goal Setting & 9.21 & 9.23 & 9.36 & 9.25 & 9.00 & 9.27 & 0.981 \\
\hline Information Seeking & 10.27 & 10.67 & 10.32 & 10.48 & 9.65 & 10.19 & 0.032 \\
\hline Systematic Planning & 10.49 & 10.41 & 10.64 & 10.20 & 10.03 & 10.43 & 0.830 \\
\hline Persuasion \&Networking & 10.94 & 10.59 & 10.59 & 10.83 & 9.53 & 10.49 & 0.014 \\
\hline Self-confidence & 10.03 & 10.95 & 11.64 & 10.45 & 10.50 & 11.87 & 0.013 \\
\hline
\end{tabular}

Table 6.2 Entrepreneurial Competencies of Fisherfolks according to Educational Attainment

\begin{tabular}{|c|c|c|c|c|c|c|c|}
\hline \multirow{2}{*}{$\begin{array}{c}\text { Entrepreneurial } \\
\begin{array}{c}\text { Competency } \\
\text { (Indicator) }\end{array}\end{array}$} & $\begin{array}{c}\text { College } \\
\text { Graduate }\end{array}$ & $\begin{array}{c}\text { College } \\
\text { level }\end{array}$ & $\begin{array}{c}\text { Elementary } \\
\text { Graduate }\end{array}$ & $\begin{array}{c}\text { Elementary } \\
\text { Level }\end{array}$ & $\begin{array}{c}\text { HighSchool } \\
\text { Graduate }\end{array}$ & $\begin{array}{c}\text { HighSchool } \\
\text { Level }\end{array}$ \\
\hline Opportunity Seeking & 9.33 & 10.70 & 9.32 & 9.81 & 10.21 & 10.94 & 0.174 \\
\hline Persistence & 7.33 & 9.50 & 8.84 & 9.08 & 9.67 & 10.22 & 0.025 \\
\hline Commitment To Work & 11.33 & 10.40 & 10.21 & 10.31 & 10.88 & 10.89 & 0.506 \\
\hline Demand for Quality & 9.33 & 10.00 & 9.53 & 9.69 & 9.83 & 10.00 & 0.957 \\
\hline Risk Taking & 11.33 & 13.90 & 13.47 & 12.73 & 12.75 & 13.78 & 0.463 \\
\hline Goal Setting & 9.67 & 8.90 & 8.68 & 9.08 & 9.33 & 9.72 & 0.660 \\
\hline Information Seeking & 10.33 & 9.50 & 9.90 & 10.11 & 9.88 & 11.17 & 0.103 \\
\hline Systematic planning & 10.33 & 10.30 & 10.58 & 9.81 & 9.88 & 10.00 & 0.806 \\
\hline Persuasion \&Networking & 10.33 & 9.90 & 9.42 & 9.15 & 10.17 & 10.67 & 0.178 \\
\hline Self-confidence & 10.67 & 9.50 & 9.58 & 10.23 & 9.96 & 10.33 & 0.642 \\
\hline
\end{tabular}


College graduates have the lowest competency (10.03). It was observed that farmers who are high school level gain more self-confidence in farming because of their long commitment in farming so their experience provided them their competency for self-confidence.

\section{D.3.2 Differences on Entrepreneurship Competencies ofFisherfolks According to Educational Attainment}

Results of One-factor ANOVA one-way was reflected in table 6.2 which shows significant differences on personal entrepreneurial competencies along educational attainment under persistence $(p=0.025)$. Post Hoc analysis shows high school level has the highest competency (10.22). There is no significant difference between high school graduate (9.67) and college level (9.50), but they are higher than elementary level (9.08) and elementary graduate (8.84). The lowest competency is observed among college graduate (7.33). The rest of the indicators show no significant differences among educational attainment.

It was observed that only persistence competency has significant difference along educational attainment. The level of persistency of fisherfolks varied on their educational attainment. High school level fisherfolks are more persistent and elementary graduate are least. It was noted that the high school level fisherfolks are persistent to improve and levelup their fishing activity or trading despite their lack of educational attainment.

\section{E. Framework in implementing community-based} enterprise for farmers and fisherfolks.

In Figure 1 it reflects the framework in implementing the community-based enterprise for farmers and fisherfolks. First, it will start from assessing and identifying the level of personalentrepreneurial competency of the farmers and fisherfolks who are the main actor for the community-based enterprise.Second, it will design the training program that will enhance the level of personal entrepreneurial competency of farmers \& fisherfolks to help them equip to manage the operation of their community-based enterprise.

The training design formulated by International Labor Organization (ILO) for the Community-Based Enterprise Development (C-BED) program will be use in this framework. C-BED's goal is to empower entrepreneurs through peer-to-peer workshops, it adopts an innovative methodology for peer-based learning through networking and activities; low cost and straightforward to implement, it is particularly appropriate for harder to reach entrepreneurs (ILO) or aspiring entrepreneurs just like farmers and fisherfolks. It will have two phases of trainings: phase 1 includes training on orientation to entrepreneurship; basic financial literacy; and aspiring entrepreneurs.

While phase 2 includes trainings about small business owner; financial education for business planning; orientation to working capital and microfinance; and tool for business plan development. However, these two phases of training will have separate implementation. Third, organizing the farmers and fisherfolks into a community-based enterprise and providing capacity training for leadership and management of their organization. Four, implementation of phase 2 of the training for community-based enterprise development. There was evidence that C-BED training had an inspiring impression on practices that boost income security. Fifth, monitoring and assisting the community-based enterprise established by farmers and fisherfolks.

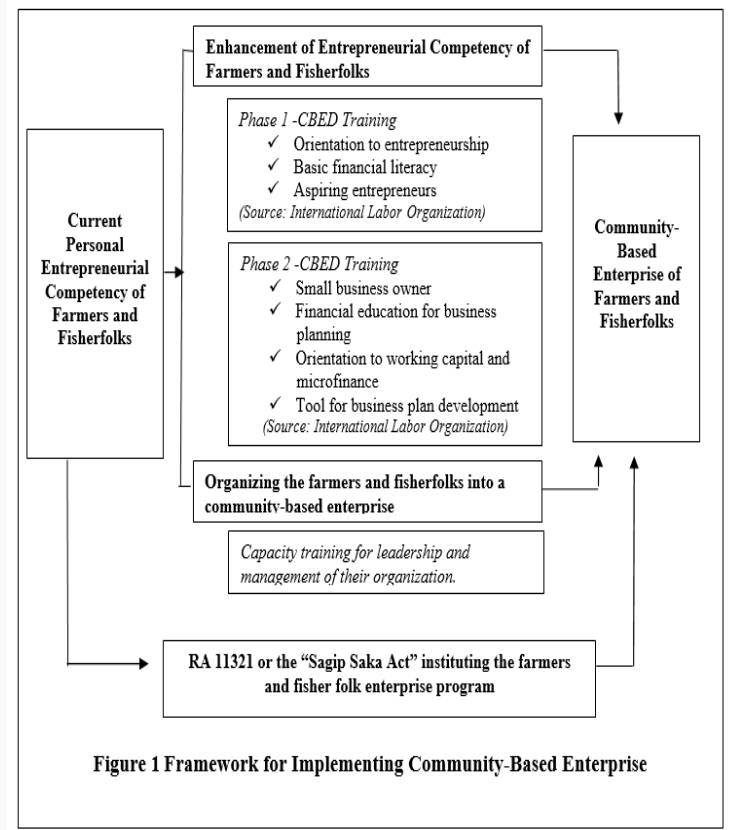

\section{CONCLUSION}

Assessing the level of personal entrepreneurial competency of farmers and fisherfolks will help in the development of community based-enterprise for farmers and fisherfolks. Also, in the implementation of the RA 11321 or the "Sagip Saka Act" an act instituting the farmers and fisher folk enterprise program of the department of agriculture which aims to ensure sustainability of agriculture and fishing enterprise.

Farmers and fisherfolks have an overall moderate competency to the ten (10) indicators of personal entrepreneurial competency such as oopportunity seeking, persistence, commitment to work, demand for quality, risk taking, goal setting, information seeking, systematic planning, persuasion \& networking, and self-confidence. It was noted that both farmers and fisherfolks rank first the risk taking in their entrepreneurial competency and goal setting as the least. It shows that farmers entrepreneurial competency for self-confidence increases as they aged while for fisherfolks it declines; male farmers are more persuasive than their counterpart, farmers with business experience has higher competency for opportunity seeking and risk taking than those without business experience, and for farmers personal entrepreneurial competency for risk taking; information seeking; persuasion and networking; and self- 
confidence varied in term of their educational attainment. While for fisherfolks shows no difference on entrepreneurial competency for both men and women, with or without business experience, and only the competency for persistence vary in terms of their educational attainment.

Therefore, with the current level of personal entrepreneurial competency of farmers and fisherfolks it would need enhancement trainings for them to improve their competency from moderate to very strong to help them become more entrepreneurial and improve their livelihood. Likewise, before the farmers and fisherfolks engage in communitybased enterprise development/engagement they must be able to acquire first the necessary competency just like the ten (10) indicators of personal entrepreneurial competency. Farmers and fisherfolks would need to undergo training for community-based enterprise development and capacity training for leadership and management of enterprise.

\section{REFERENCES}

[1]. Anderson, R. B., Honig, B., \& Peredo, A. M. (2006).Communities in the new economy: where socialentrepreneurship and Indigenous entrepreneurship [1]meet. In C. Steyaertt\& D. Hjorth (Eds.), Entrepreneurship as Social Change. Cheltenham: Edward Elgar.

[2]. Ali, Z., \& Bhaskar, S. B. (2016). Basic statistical tools in research and data analysis, Indian Journal of Anaesthesia, 60(9). 662. https://doi: 10.4103/0019-5049.190623

[3]. Arellano, C.A., Delos Reyes, J.A. (2019). Effects of Farmer Entrepreneurial Competencies on the Level of Production and Technical Efficiency of Rice FarmsinLaguna,Philippines.https://www.cabdirect.org/cabdirect/a bstract/20203150053

[4]. Asence, E. E. III. (2016). "Entrepreneurial Competencies of Farmers and Its impact on the Performance of the Sustainable Agriculture for Rural Income Growth Program of Naga City, Philippines," Paper presented at the 8th International Conference on Agribusiness Economics and Management, Davao City, Philippines, 26-28 October 2016. http://ojs.upmin.edu.ph/index.php/banwa-suppl/article/view/227

[5]. Bailey, N. (2012). The role, organisation and contribution of community enterprises to urban regeneration policy in the UK. Progress in Planning, 77(1),1-35. https://doi.org/10.1016/j.progress.2011.11.001

[6]. Baticados, G. (2018). Best Practices of Agri-entrepreneurs in the Philippines. Retrieve from http://ap.fftc.agnet.org/ap_db.php?id=921.

[7]. Bergevoet, R., Giesen, G., Saatkamp, H., van Woerkum, C., Huirne, R. (2005). Improving entrepreneurship in farming: The impact of a training programme in dutch dairy farming. 15th Congress -Developing Entrepreneurship Abilities to Feed the

[8]. World in a Sustainable Way Caning, M.C., Casaul, E., Rodriquez, J.A., Villamor, E., \& Arce A. (2018). Developing a framework for academe-community partnership through farm tourism: The case of a state university in Bicol Region. Retrieved from https://nbmconference.files.wordpress.com/2019/01/ 6nbmc-conference-proceedings-issn- 2345-8720.pdf

[9]. Cieslik, K. (2016). Moral economy meets social enterprise community-based green energy project in rural Burundi. World Development, 83(1), 12-26.

[10]. Daskalaki, M., Hjorth, D., \& Mair, J. (2015). Are entrepreneurship, communities, and social transformation related. Journal of Management Inquiry, 24(4), 419-423. http://dx.doi.org/10.1177/1056492615579012

[11]. Depositario, D. P. T., Aquino, N. A. and Feliciano, K. C. (2011). Entrepreneurial skills development needs of potential technopreneurs. Journal of International Society for Southeast
Asian Agricultural Sciences,17(1):106-120.

https://agris.fao.org/agris-

search/search.do?recordID=PH2013000240

[12]. Dubb, S. (2016). Community wealth building forms: What they are and how to use them atthe local level. The Academy of Management Perspectives, 30(2), 141-152. http://dx.doi.org/10.5465/amp.2015.0074

[13]. García-López, G. (2013). Scaling up from the grassroots and the top down: The impacts of multi-level governance on community forestry in Durango,Mexico. International Journal of the Commons, 7(2), 406-431.

[14]. Giovannini, M. (2014). Alternatives to Development: The Contribution of Indigenous Community Enterprises in Chiapas. Journal of International Development, 28(7), 1138-1154.

[15]. Hall, A. 2010. Entrepreneurs: What sort do we really need? Learning Innovation Knowledge: Policy Relevant Resources for Rural Innovation. United Nations University UNU-MERIT. p. 2

[16]. Handy, F., Cnaan, R. A., Bhat, G., \&Meijs, L. C. (2011). Jasmine growers of coastal Karnataka:Grassroots sustainable community-based enterprise in India. Entrepreneurship \& Regional Development, 23(5-6), 405-417.

[17]. Haugh, H. (2007). Community-led social venture creation. Entrepreneurship Theory and Practice, 31(2), 161-182.

[18]. Heinart, S. \& Roberts, G. (2016). Engaging Rural Youth in Entrepreneurship through Extracurricular and Co- Curricular Systems.https://agrilinks.org/sites/default/files/resource/files/Hei nertRobertsFINAL.pdf

[19]. Herliana, S., Aina, Q., Sutardi, A., Lawiyah, N., Ulfah, W.N. (2019). Analysis of the Competency on Agribusiness Activities in Developing and Developed Countries. https://www.abacademies.org/articles/analysis-of-thecompetency-on-agribusiness- activities-in-developing-anddeveloped-countries-8489.html

[20]. Hertel, C. J., \& Belz, F.-M. (2017). Community entrepreneurship - A systematic review, conceptual clarifications and avenues for future research. Working paper presented at the Annual Meeting of the Academy of Management, August 2017, Atlanta, Georgia. https://doi.org/10.5465/AMBPP.2017.11199abstract

[21]. Johnstone, H., \&Lionais, D. (2004). Depleted communities and community business revaluing space through place. Entrepreneurship \&Regional Development, 16(3), 217-233.

[22]. Kahan, D. 2013. Entrepreneurship in farming. Retrieved fromhttp://www.fao.org/uploads/media/5EntrepreneurshipInternLores.pdf August 26, 2013.

[23]. Kahan, D. (2012). Entrepreneurship in Farming. Food and Agriculture Organization of the United Nation. Retrieved from http://www.fao.org/uploads/media/EntrepreneurshipInternLores.p df

[24]. Korsgaard,S. , Ferguson, R., Gaddefors, J. (2015). The Best of Both Worlds: How Rural Entrepreneurs Use Placial Embeddedness and Strategic Networks to Create Opportunities. Taylor \& Francis Group in Entrepreneurship and Regional Development, available online: http://dx.doi.org/10.1080/08985626.2015.1085100.

[25]. Lans, T., Verstegen, J., Mulder, M., (2008). Analysing, pursuing and networking: Towards a validated three-factor framework for entrepreneurial competence from a small firm perspective. International Small Business Journal 29(6) 695-713. DOI: $10.1177 / 0266242610369737$.

[26]. Lawson, L., \& Kearns, A. (2010). Communityengagement in regeneration: are we getting the point? Journal of Housing and the Built Environment, 25, 19-36.

[27]. Lumpkin, G. T., Bacq, S., \&Pidduck, R. J. (2018). Where change happens: Community-level phenomena in social entrepreneurship research. Journal of Small Business Management,56(1), 24-50.

[28]. Maguire, K., \& Truscott, F. (2006). Active governance: the value added by community involvement in governance through local strategic partnerships. United Kingdom: Joseph Rowntree Foundation.

[29]. Man, T., Lau, T. \& Chan, K. (2002). The competitiveness of small and medium enterprises: A conceptualization with focus on entrepreneurial competencies. Journal of Business Venturing, vol. 
17, issue $2, \quad 123-$ 142.https://ideas.repec.org/a/eee/jbvent/v17y2002i2p123142.html.

[30]. McElwee, G., (2008). A taxonomy of entrepreneurial farmers. International Journal of Entrepreneurship and Small Business 6(3). DOI: 10.1504/IJESB.2008.019139.

[31]. Mubarak, A., Irham, Jangkung, H.M., Hartono, S. (2019). The influence of entrepreneurship characteristics and competencies on farmers'entrepreneurial intentions in the border region of North Borneo. http://doi; 10.1088/1755-1315/250/1/012109.

[32]. Nieuwoudt, S., Henning, J. I.F., \& Jordaan, H. (2017). Entrepreneurial competencies and financial performance of farmers in South Africa. South African Journal of Economic and Management Sciences, 20(1),1-13. https://doi.org/10.4102/sajems.v20i1.1640

[33]. Quilloy, K. (2015). Empowering Small Farmers through Cooperative: The Success Story of Subasta Integrated Farmers Multi-Purpose Cooperative. International Review of Management and Business Research, Vol.4 Issue 1. https://www.irmbrjournal.com/papers/1429171601.pdf

[34]. Parwez, S. Community-based entrepreneurship: evidences from a retail case study. J InnovEntrep 6, 14 (2017). https://doi.org/10.1186/s13731-017-0074-Z

[35]. Peredo, A. M., \& Chrisman, J. J. (2006). Toward a theory of community-based enterprise. Academy of Management Review, 31(2), 309-328.

[36]. Phelan, C., \& Sharpley, R. (2012). Exploring entrepreneurial skills and competencies in farm tourism, Local Economy, 27(2), 103-118. DOI: $10.1177 / 0269094211429654$

[37]. Phelan,C.\& Sharpley, R. (2011). Exploring Agritourism Entrepreneurship in the UK, Tourism Planning \& Development, 8:2, 121-136, DOI: $10.1080 / 21568316.2011 .573912$

[38]. Peredo, A. M., \& Chrisman, J. J. (2006). Toward a theory of community-based enterprise. Academy of Management Review, 31(2), 309-328. [31] https://www.jstor.org/stable/20159204

[39]. RA 11321 or the "Sagip Saka Act". https://www.da.gov.ph/wpcontent/uploads/2019/11/ac08_s2019.pdf Rahi, S. (2017). Research design and methods: A systematic review of research paradigms, sampling issues and instruments development. International Journal of Economics \& Management Sciences, 6(2), 1-5. DOI: 10.4172/2162-6359.1000403.

[40]. Rydin, Y., \& Pennington, M. (2000). Public participation and local environmental planning: the collective action problem and the potential of social capital. Local Environment, 5, 153-169.

[41]. Torri, M. C., \& Martinez, A. (2011). Gender empowerment and equality in rural India: are women's community-based enterprises the way forward?. Journal of International Women's Studies, 12(1), 157.

[42]. United Nations. (2015). Transforming our world: The 2030 agenda for sustainable development. A/RES/70/1, 21 October. Available at: http://www.un.org/ga/search/view doc.asp?symbol=A/RES/70/1\&Lang=E

[43]. UNDP. (2018). Annual report 2017. Available at:https://annualreport2017.undp.org/assets/UNDP- AnnualReport-Final-June-1.pdf.

[44]. UNDP Environment and Energy Group. (2010). The local capacity strategy: Enabling action for the environment and sustainable development. Available at:

https://www.undp.org/content/dam/aplaws/publication/en/publica tions/environment-energy/www-ee-library/localdevelopment/undps-local-capacity strategy/Local\%20Capacity\%20Strategy\%20-\%20Final.pdf.

[45]. Valchovska, S., \& Watts, G. (2016). Interpreting CommunityBased Enterprise: A Case Study from Rural Wales. Journal of Social Entrepreneurship, 7(2), 211-235.

DOI: $10.1080 / 19420676.2016 .1158731$

[46]. Vergara, M.P. (2018). Structural Effects of Entrepreneurial Competency to the Organic Agriculture Industry of the Davao Region. Retrieved from https://nbmconference.files.wordpress.com/2019/01/c6nbmconfe rence-proceedings-issn-2345-8720.pdf.

[47]. Welsch, H., \& Kuhns, B. (2001). Community-Based Enterprises: Propositions and https://citeseerx.ist.psu.edu/viewdoc/download? doi $=10.1 .1 .198 .4265 \&$ rep=rep1\&type $=$ pdf 